\title{
Synthesis, Molecular Modeling, and Biological Activity of Zinc(II) Salts with 1,4-Bis(benzimidazol-2-yl)benzene
}

\author{
G. Krishnamurthy \\ Department of Chemistry, Sahyadri Science College (Autonomous), Kuvempu University, Shimoga-577203, Karnataka, India \\ Correspondence should be addressed to G. Krishnamurthy; gkmnaik_sahyadri@yahoo.co.in
}

Received 22 June 2012; Revised 10 August 2012; Accepted 10 August 2012

Academic Editor: Narcis Avarvari

Copyright (C) 2013 G. Krishnamurthy. This is an open access article distributed under the Creative Commons Attribution License, which permits unrestricted use, distribution, and reproduction in any medium, provided the original work is properly cited.

Zinc(II) halides and perchlorate react with 1,4-bis(benzimidazol-2-yl)benzene (L) in 1:2 molar ratio in n-butanol/2-methoxy ethanol $(10 \mathrm{~mL})$ at refluxing temperature to produce white/pale yellow-colored complexes of the formulae $\left[\mathrm{ZnCl}_{2} \mathrm{~L}\right] \mathrm{H}_{2} \mathrm{O}$, $\left[\mathrm{ZnBr}_{2} \mathrm{~L}\right] 3 \mathrm{H}_{2} \mathrm{O}$, and $\left[\mathrm{Zn}\left(\mathrm{OClO}_{3}\right)_{2} \mathrm{~L}\right] \mathrm{HOCH}_{2} \mathrm{CH}_{2} \mathrm{CH}_{2} \mathrm{CH}_{3}$. Zinc(II) iodide also reacts with $\mathrm{L}$ in $1: 2$ molar ratio in n-butanol $\left(\mathrm{HOCH}_{2} \mathrm{CH}_{2} \mathrm{CH}_{2} \mathrm{CH}_{3}\right)$ to yield white-colored complex of the formula $\left[\mathrm{ZnL}_{2}\left(\mathrm{OCH}_{2} \mathrm{CH}_{2} \mathrm{CH}_{2} \mathrm{CH}_{3}\right)_{2}\right]$. The complexes were characterized by elemental analysis, molar conductance measurements, thermal analysis, and IR, ${ }^{1} \mathrm{H}-,{ }^{13} \mathrm{C}$-NMR spectral studies. The complexes showed significant anthelmintic activity. The minimum energy configuration has been obtained for the zinc complexes using molecular modeling Pro Plus; a tool developed by ChemSW, inc, USA.

\section{Introduction}

Transition metal complexes containing bis-benzimidazolyl derivatives have been extensively studied. Several of these benzimidazolyl derivatives could modify their reactivity towards metal ions [1-6]. The zinc(II) is responsible for the function of carboxy peptidase A and carbonic anhydrase in biological systems [7-9]. Further, a number of $\mathrm{Zn}$ (II) complexes with variety of ligand show antimicrobial, anticarcinogenic, veterinary, anthelmintic, and poliovirus inhibitor activities [10-13]. Thus, the coordination behaviour of benzimidazoles with zinc is of considerable importance. In this contest, I report here the synthesis and characterization of zinc(II) complexes containing 1,4-bis(benzimidazol-2yl)benzene and their anthelmintic activity.

1.1. Reagents. The hydrated zinc(II) chloride was used as supplied (BDH). Terephthalic acid and o-phenylenediamine were from Merck Chemicals. The solvents used were from Merck Chemicals and they were purified according to literature methods [14]. Hydrated zinc(II) bromide, zinc(II) iodide, and zinc(II) perchlorate salts were prepared by dissolving the metal in hydrobromic acid, hydroiodic, acid and perchloric acid, respectively, followed by filtration of obtained precipitate and careful evaporation nearly to dryness under reduced pressure.

Drugs: Albendazole (BANDY, Mankind Pharma Ltd., New Delhi),Piperazine citrate, Tween 80.

1.2. Measurements. $\mathrm{C}, \mathrm{H}$, and $\mathrm{N}$ analyses were carried out on a Carlo Erba Microanalyser. IR spectra (in nujol) were recorded on a Nicolet 4000D spectrophotometer. Molar conductivity measurements were made with $10^{-3} \mathrm{M}$ solution in dimethylformamide (DMF) using a digital (SYSTRONICS) conductivity meter-304 with a conventional dip-type conductivity cell with a cell constant $1.00 \mathrm{~cm}^{-1}$. NMR spectra were recorded (in DMSO- $\mathrm{d}_{6}$ ) on a Bruker WH-270 or AMX$400 \mathrm{MHz}$ spectrometer using TMS as the internal standard. The thermograms were recorded on a Shimadzu Thermal Analyzer DT30 at a heating rate of $5^{\circ} \mathrm{C} /$ minute.

1.3. Preparation of the Ligand(1,4-Bis(benzimidazol-2$y$ l)benzene). The ligand was prepared according to the literature method [15]. Terephthalic acid $(10 \mathrm{mmole})$ was stirred with $o$-phenylenediamine $(20 \mathrm{mmole})$ in syrupy phosphoric acid $(20 \mathrm{~mL})$ at $240^{\circ} \mathrm{C}$ for $4 \mathrm{~h}$. The coloured melt was poured into cold water $(500 \mathrm{~mL})$ with stirring to obtain a blue-green-coloured precipitate. The precipitate 
TABLE 1: Physical properties and analytical data of the complexes.

\begin{tabular}{|c|c|c|c|c|c|c|}
\hline \multirow{2}{*}{ Complex } & \multirow{2}{*}{ Color } & \multirow{2}{*}{ M.P $\left({ }^{\circ} \mathrm{C}\right)$} & \multirow{2}{*}{$\begin{array}{c}\Delta_{M}{ }^{\mathrm{a}} \\
\Omega^{-1} \mathrm{~cm}^{2} \mathrm{moL}^{-1}\end{array}$} & \multicolumn{3}{|c|}{ Found (calcd.\%) } \\
\hline & & & & $\mathrm{C}$ & $\mathrm{H}$ & $\mathrm{N}$ \\
\hline$\left[\mathrm{ZnCl}_{2} \mathrm{~L}\right] \mathrm{H}_{2} \mathrm{O}$ & Buff & $>260$ & 17 & $51.3(51.7)$ & $3.6(3.5)$ & $11.6(12.1)$ \\
\hline$\left[\mathrm{ZnBr}_{2} \mathrm{~L}\right] 3 \mathrm{H}_{2} \mathrm{O}$ & Pale-yellow & $>260$ & 25 & $41.3(42.0)$ & $3.8(3.2)$ & $8.6(9.0)$ \\
\hline$\left[\mathrm{ZnL}_{2}\left(\mathrm{OCH}_{2} \mathrm{CH}_{2} \mathrm{CH}_{2} \mathrm{CH}_{3}\right)_{2}\right]$ & White & $>260$ & 16 & $68.8(69.3)$ & $4.7(5.6)$ & $14.0(13.5)$ \\
\hline$\left[\mathrm{Zn}\left(\mathrm{OClO}_{3}\right)_{2} \mathrm{~L}\right] \mathrm{HOCH}_{2} \mathrm{CH}_{2} \mathrm{CH}_{2} \mathrm{CH}_{3}$ & Yellow & $>250$ & 13 & $43.9(44.4)$ & $4.2(3.7)$ & $9.5(8.6)$ \\
\hline
\end{tabular}

${ }^{\mathrm{a}}$ Molar conductance of $\sim 10^{-3} \mathrm{M}$ solutions at $25^{\circ} \mathrm{C}$ in DMF.

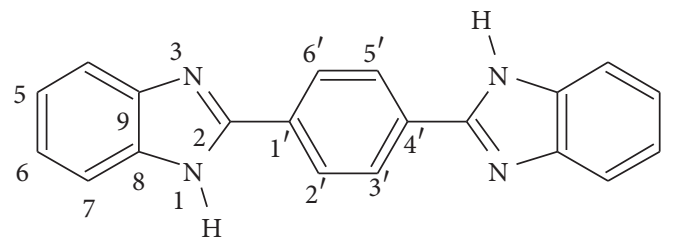

FiguRE 1: Structure of 1,4-bis(benzimidazol-2-yl)benzene.

was neutralized with $10 \%$ aqueous sodium carbonate solution. The resulting solid was recovered by filtration and recrystallized from ethanol to obtain a pale-pink compound (Figure 1). (yield 50\%).

\subsection{Preparation of the Complexes}

1.4.1. $\left[\mathrm{ZnCl}_{2} \mathrm{~L}\right] \mathrm{nH}_{2} \mathrm{O}(\mathrm{X}=\mathrm{Cl}, n=1 ; X=\mathrm{Br}, n=3)$. To a solution of zinc(II) halide $(1 \mathrm{mmol})$ dissolved in 2methoxyethanol/n-butanol $(10 \mathrm{~mL})$, the ligand $(2 \mathrm{mmol})$ in the same solvent $(15 \mathrm{~mL})$ was added and the mixture was refluxed for $6-8 \mathrm{~h}$, followed by concentration of the mixture under reduced pressure, during which time a buff/white/paleyellow solid separated. This was filtered, washed with petroleum benzene $40-60^{\circ} \mathrm{C}(20 \mathrm{~mL})$, and dried in a vacuum (yield 65\%).

1.4.2. [ $\mathrm{ZnL}\left(\mathrm{OCH}_{2} \mathrm{CH}_{2} \mathrm{CH}_{2} \mathrm{CH}_{3}\right)_{2}$ ]. To a solution of hydrated zinc(II) iodide $(1 \mathrm{mmol})$ in $\mathrm{n}$-butanol $(20 \mathrm{~mL})$, the ligand $(2 \mathrm{mmol})$ in $\mathrm{n}$-butanol $(20 \mathrm{~mL})$ was added. The resulting mixture was refluxed for $4-6 \mathrm{~h}$. The solution was concentrated under reduced pressure when a white-coloured solid separated. The solid was filtered, washed with petroleum benzene $40-60^{\circ} \mathrm{C}(20 \mathrm{~mL})$, and dried in a vacuum (yield 60-70\%).

1.4.3. $\left[\mathrm{Zn}\left(\mathrm{OClO}_{3}\right)_{2} \mathrm{~L}\right] \mathrm{HOCH}_{2} \mathrm{CH}_{2} \mathrm{CH}_{2} \mathrm{CH}_{3}$. Zinc(II) perchlorate $(1 \mathrm{mmol})$ was dissolved in $\mathrm{n}$-butanol $(5 \mathrm{~mL})$, then the ligand $(2 \mathrm{mmol})$ in $n$-butanol $(10 \mathrm{~mL})$ was added. The resulting mixture was refluxed for $6 \mathrm{~h}$ when a paleyellow solid separated. This solid was filtered, washed with petroleum benzene $40-60^{\circ} \mathrm{C}(20 \mathrm{~mL})$, and dried in a vacuum (yield 60\%).

1.5. Procedure for Anthelmintic Activity. The anthelmintic assay was carried out as for the method of Ajaiyeoba et al. [16]. Indian adult earthworms Pheretima posthuma. The worms were procured from local supplier at Shimoga at the time of carrying out the experiment. The worms were washed with normal saline to remove all fecal matter used for the anthelmintic study. The earthworms of $4-6 \mathrm{~cm}$ in length and $0.3-0.4 \mathrm{~cm}$ in width were used for all experimental protocol due to its anatomical and physiological resemblance with intestinal roundworms parasite of human beings. The cleaned and uniform-size worms were kept in 6\% dextrose solution for acclimating. The worms with normal motility were selected for the activity. In a separate Petri dish a, $2 \mathrm{~mL}$ of each test compound $(5 \mathrm{mg} / \mathrm{mL})$ in $0.1 \%$ Tween- 20 suspension were placed and the volume was made up to $25 \mathrm{~mL}$ with an aqueous solution of dextrose $(6 \%)$. The albendazole solution was served as standard. In each petri dish, one earth worm was placed. The time taken by the worm for paralysis was noted and the paralysis of worm was tested by placing the worm in water maintained at $50^{\circ} \mathrm{C}$. Nonmotility at $50^{\circ} \mathrm{C}$ was taken as the death of the worm and correspondingly the time taken for the death was recorded.

Synthesized complexes were dissolved separately in minimum amount of Tween 80 and then volume was adjusted to $25 \mathrm{~mL}$ with dextrose solution. All solutions were freshly prepared before starting the experiment. Four groups of six earthworms each were released into $25 \mathrm{~mL}$ of desired formulation as follows:

(1) vehicle: $5 \%$ Tween 80 in dextrose solution,

(2) albendazole,

(3) piperazine citrate,

(4) ligand (L),

(5) $\left[\mathrm{ZnCl}_{2} \mathrm{~L}\right] \mathrm{H}_{2} \mathrm{O}$,

(6) $\left[\mathrm{ZnBr}_{2} \mathrm{~L}\right] 3 \mathrm{H}_{2} \mathrm{O}$,

(7) $\left[\mathrm{ZnL}_{2}\left(\mathrm{OCH}_{2} \mathrm{CH}_{2} \mathrm{CH}_{2} \mathrm{CH}_{3}\right)_{2}\right]$,

(8) $\left[\mathrm{Zn}\left(\mathrm{OClO}_{3}\right)_{2} \mathrm{~L}\right] \mathrm{HOCH}_{2} \mathrm{CH}_{2} \mathrm{CH}_{2} \mathrm{CH}_{3}$.

\section{Results and Discussion}

The physical properties and analytical data of the complexes are listed in Table 1.The complexes are insoluble in common organic solvents but are soluble in DMF and DMSO and show low conductivity in DMF at room temperature $\left(25^{\circ} \mathrm{C}\right)$. This may arise from the replacement of the halide by DMF in solution and the existence an equilibrium of the type below [17]:

$$
\mathrm{ZnX}_{2} \mathrm{~L}+\mathrm{DMF} \leftrightarrow[\mathrm{ZnX}(\mathrm{DMF}) \mathrm{L}]^{+}+\mathrm{X}^{-}
$$


TABle 2: ${ }^{1} \mathrm{H}-\mathrm{NMR}$ spectral data of the ligand and complexes in DMSO-d ${ }_{6}(\delta$ in p.p.m).

\begin{tabular}{lccccccccc}
\hline Compound & ${\mathrm{H}-2^{\prime}}^{\mathrm{a}}$ & $\mathrm{H}-3^{\prime}$ & $\mathrm{H}-5^{\prime}$ & $\mathrm{H}-6^{\prime}$ & $\mathrm{H}-4$ & $\mathrm{H}-5$ & $\mathrm{H}-6$ & $\mathrm{H}-7$ & $\mathrm{~N}-\mathrm{H}$ \\
\hline $\mathrm{L}$ & $8.35 \mathrm{~s}$ & $8.35 \mathrm{~s}$ & $8.35 \mathrm{~s}$ & $8.35 \mathrm{~s}$ & $7.41 \mathrm{~d}$ & $7.23 \mathrm{~m}$ & $7.25 \mathrm{~m}$ & $7.69 \mathrm{~d}$ & $13.05 \mathrm{~s}$ \\
{$\left[\mathrm{ZnCl}_{2} \mathrm{~L}\right] \mathrm{H}_{2} \mathrm{O}$} & $8.35 \mathrm{~s}$ & $8.35 \mathrm{~s}$ & $8.35 \mathrm{~s}$ & $8.35 \mathrm{~s}$ & $7.72 \mathrm{~d}$ & $7.24 \mathrm{t}$ & $7.24 \mathrm{t}$ & $7.56 \mathrm{~d}$ & $13.04 \mathrm{~s}$ \\
& - & - & - & - & $(-0.31)$ & $(0.01)$ & $(-0.01)$ & $(-0.13)$ & $(-0.01)$ \\
& $8.43 \mathrm{~s}$ & $8.43 \mathrm{~s}$ & $8.43 \mathrm{~s}$ & 8.43 & $7.76 \mathrm{q}$ & $7.41 \mathrm{~m}$ & $7.41 \mathrm{~m}$ & $7.75 \mathrm{q}$ & 13.05 \\
{$\left[\mathrm{ZnBr}_{2} \mathrm{~L}\right] \cdot 3 \mathrm{H}_{2} \mathrm{O}$} & $(0.07)$ & $(0.08)$ & $(0.08)$ & $(0.08)$ & $(0.35)$ & $(0.18)$ & $(0.16)$ & $(0.06)$ & - \\
& $8.34 \mathrm{~s}$ & 8.34 & 8.34 & 8.34 & $7.68 \mathrm{~d}$ & $7.55 \mathrm{t}$ & $7.23 \mathrm{t}$ & $7.23 \mathrm{t}$ & $13.03 \mathrm{~s}$ \\
{$\left[\mathrm{ZnL}_{2}\left(\mathrm{OCH}_{2} \mathrm{CH}_{2} \mathrm{CH}_{2} \mathrm{CH}_{3}\right)_{2}\right]$} & $(-0.01)$ & $(-0.01)$ & $(-0.01)$ & $(-0.01)$ & $(0.27)$ & $(0.32)$ & $(-0.02)$ & $(-0.46)$ & $(-0.02)$ \\
& $8.36 \mathrm{~s}$ & $8.36 \mathrm{~s}$ & $8.36 \mathrm{~s}$ & 8.36 & $7.65 \mathrm{~b}$ & $7.25 \mathrm{~s}$ & 7.25 & $7.65 \mathrm{~b}$ & 13.04 \\
{$\left[\mathrm{Zn}\left(\mathrm{OClO}_{3}\right)_{2} \mathrm{~L}\right] \mathrm{HOCH}_{2} \mathrm{CH}_{2} \mathrm{CH}_{2} \mathrm{CH}_{3}$} & $(0.01)$ & $(0.01)$ & $(0.01)$ & $(0.01)$ & $(0.24)$ & $(0.02)$ & - & $(-0.04)$ & $(-0.01)$ \\
\hline
\end{tabular}

${ }^{\mathrm{a}}$ Spectra recorded in dmso- $\mathrm{d}_{6}$, s: singlet, d: doublet, t: triplet, m: multiplet, b: broad.

*Values in the parentheses are coordination induced shifts (c.i.s) $=\delta_{\text {complex }}-\delta_{\text {ligand }}$.

TABLE $3:{ }^{13}$ C-NMR spectral data of the ligand and complexes (in $\delta$ p.p.m).

\begin{tabular}{|c|c|c|c|c|c|c|c|c|c|c|}
\hline Compound $^{\mathrm{a}}$ & $\mathrm{C}-1^{\prime}$ & $\mathrm{C}-2^{\prime}$ & $C-6^{\prime}$ & $\mathrm{C}-2$ & C- 4 & C-5 & $\mathrm{C}-6$ & C-7 & C- 8 & C-9 \\
\hline $\mathrm{L}$ & $131.19 \mathrm{~s}$ & $126.92 \mathrm{~s}$ & $126.92 \mathrm{~s}$ & $143.94 s$ & $111.41 \mathrm{~s}$ & $121.85 \mathrm{~s}$ & $119.01 \mathrm{~s}$ & $122.81 \mathrm{~s}$ & $143.94 \mathrm{~s}$ & $131.19 \mathrm{~s}$ \\
\hline$\left[\mathrm{ZnL}_{2}\left(\mathrm{OCH}_{2} \mathrm{CH}_{2} \mathrm{CH}_{2} \mathrm{CH}_{3}\right)_{2}\right]$ & $\begin{array}{l}131.17 \mathrm{~s} \\
(-0.02)\end{array}$ & $\begin{array}{l}126.91 \mathrm{~s} \\
(-0.01)\end{array}$ & $\begin{array}{l}126.91 \mathrm{~s} \\
(-0.01)\end{array}$ & $\begin{array}{l}143.92 \mathrm{~s} \\
(-0.02)\end{array}$ & $\begin{array}{c}111.41 \mathrm{~s} \\
(0.00)\end{array}$ & $\begin{array}{c}121.85 \mathrm{~s} \\
-\end{array}$ & $\begin{array}{l}119.00 \mathrm{~s} \\
(-0.01)\end{array}$ & $\begin{array}{c}122.81 \mathrm{~s} \\
(0.0)\end{array}$ & $\begin{array}{c}150.61 \mathrm{~s} \\
(6.67)\end{array}$ & $\begin{array}{c}132.17 \mathrm{~s} \\
(0.98)\end{array}$ \\
\hline$\left.\left[\mathrm{Zn}\left(\mathrm{OClO}_{3}\right)_{2} \mathrm{~L}\right] \mathrm{HO}\left(\mathrm{CH}_{2}\right)_{3} \mathrm{CH}_{3}\right]$ & $\begin{array}{l}130.25 \mathrm{~s} \\
(-0.84)\end{array}$ & $\begin{array}{c}127.16 \mathrm{~s} \\
(0.24)\end{array}$ & $\begin{array}{c}127.16 \mathrm{~s} \\
(0.24)\end{array}$ & $\begin{array}{l}137.50 \mathrm{~s} \\
(-6.44)\end{array}$ & $\begin{array}{c}114.91 \mathrm{~s} \\
(3.50)\end{array}$ & $\begin{array}{c}123.01 \mathrm{~s} \\
(1.16)\end{array}$ & $\begin{array}{l}114.91 \\
(-4.10)\end{array}$ & $\begin{array}{c}123.01 \\
(0.20)\end{array}$ & $\begin{array}{c}149.87 \mathrm{~s} \\
(5.93)\end{array}$ & $\begin{array}{l}130.25 \mathrm{~s} \\
(-0.94)\end{array}$ \\
\hline
\end{tabular}

${ }^{\mathrm{a}}$ Spectra recorded in dmso- $\mathrm{d}_{6}$, s: singlet, d: doublet, t: triplet, m: multiplet, b: broad

${ }^{*}$ Values in the parentheses are coordination induced shifts $($ c.i.s $)=\delta_{\text {complex }}-\delta_{\text {ligand }}$.

The IR spectra (in nujol mull) of the complexes are similar to the spectra of the uncoordinated N-heterocycle except for minor shifts in the positions of some of the bands and some changes in their intensities due to coordination. The complexes displayed $\nu \mathrm{N}-\mathrm{H}$ band in the range $3150-3180 \mathrm{~cm}^{-1}$ and this increased by $10-30 \mathrm{~cm}^{-1}$ as compared to that of the uncoordinated ligand. The $v \mathrm{C}=\mathrm{N}$ and $v \mathrm{C}=\mathrm{C}$ vibrations are very close to each other and occur around $1616 \mathrm{~cm}^{-1}$ as weak bands in the spectra of uncoordinated heterocycle and have been observed to shift by about $10-15 \mathrm{~cm}^{-1}$ on complexation. The shift in the position of $v \mathrm{C}=\mathrm{N}$ and $\nu \mathrm{C}=\mathrm{C}$ is suggestive of coordination of the $\mathrm{N}$-heterocycle via the tertiary nitrogen of the imidazole moiety $[18,19]$. The $v \mathrm{O}-\mathrm{H}$ of water of hydration [20] is observed around $3400 \mathrm{~cm}^{-1}$. A strong band at $1574 \mathrm{~cm}^{-1}$ and a band around $1550 \mathrm{~cm}^{-1}$ are assigned to N$\mathrm{H}$ in-plane bending vibrations of ligand and the complexes, respectively. The $\nu \mathrm{C}-\mathrm{N}$ and $\delta \mathrm{N}-\mathrm{H}$ vibrations are probably very close to one another and occur at $1320 \mathrm{~cm}^{-1}$. The band due to $\mathrm{p}$-disubstituted benzene ring vibrations occurs around 1300,1250 , and $760 \mathrm{~cm}^{-1}$. The bands due to benzimidazole ring vibrations are located around 1280,1010 , and $960 \mathrm{~cm}^{-1}$. The assignments are tentative and are based on the literature reports on related compounds $[18,19]$. However, in the infrared spectrum of $\left[\mathrm{Zn}\left(\mathrm{OClO}_{3}\right)_{2} \mathrm{~L}\right] \mathrm{HO}\left(\mathrm{CH}_{2}\right)_{3} \mathrm{CH}_{3}$ complex, in addition to the ligand bands, the peaks around 1100 and $622 \mathrm{~cm}^{-1}$ of $v_{3}$ and $v_{4}$ of perchlorate are also observed. The former band is split indicating the presence of at least one perchlorate coordinated to the metal ion [21].

The ${ }^{1} \mathrm{H}$ NMR spectra of the complexes recorded in $\mathrm{DMSO}-\mathrm{d}_{6}$ exhibit resonances due to coordinated $\mathrm{N}$ heterocycle. The spectral data of the complexes along with the assignments are compiled in Table 2. The spectra of the complexes are almost similar to those of the ligand, except for a slight shift in the positions of the signals. The X-ray crystal structure study of the ligand has been established by Bei and coworkers [15] that it has centrosymmetry. The molecule is twisted in such a way that the part of the molecule is in the plane opposite to the plane of the other part. The $\mathrm{N}-\mathrm{H}$ resonance signal occurs at $13.0 \mathrm{ppm}$. The protons of the benzene ring, which are almost equivalent, give resonance signal at $8.3 \mathrm{ppm}$, the protons of benzimidazole ring resonances are found in the range $7.2-7.8 \mathrm{ppm}[22,23]$. In addition to the ligand resonance signals, the resonance signals due to the protons of $\mathrm{n}$ butanol are also observed in $\left[\mathrm{ZnL}_{2}\left(\mathrm{OCH}_{2} \mathrm{CH}_{2} \mathrm{CH}_{2} \mathrm{CH}_{3}\right)_{2}\right]$ and $\left[\mathrm{Zn}\left(\mathrm{OClO}_{3}\right)_{2} \mathrm{~L}\right] \mathrm{HOCH}_{2} \mathrm{CH}_{2} \mathrm{CH}_{2} \mathrm{CH}_{3}$ complexes. The resonance signal of $-\mathrm{CH}_{3}$ protons of $n$-butanol are located at $0.86 \mathrm{ppm}$ and signal due to $-\mathrm{CH}_{2}-$ protons are observed at $1.3 \mathrm{ppm}$. The protons of $-\mathrm{O}-\mathrm{CH}_{2}-$ group show resonance signal at $4.31 \mathrm{ppm}$. The presence of solvent molecules in the complexes was confirmed by comparison with the spectrum 
TABLE 4: Molecular modeling data.

\begin{tabular}{|c|c|c|c|c|}
\hline Compound & Total energy $(\mathrm{kJ} / \mathrm{moL})$ & \multicolumn{2}{|c|}{ Strain on metal (\%) } & Molar volume $\left(\mathrm{cm}^{3} / \mathrm{moL}\right)$ \\
\hline Ligand (A) & 334.824 & \multicolumn{2}{|c|}{-} & 264.9268 \\
\hline \multirow{3}{*}[\mathrm{ZnCl}_{2}\mathrm{L}]{$\mathrm{H}_{2} \mathrm{O}(\mathrm{B})$} & \multirow{3}{*}{969.36} & $1 \mathrm{Zn}$ & 33.46 & \multirow{3}{*}{709.4789} \\
\hline & & $2 \mathrm{Zn}$ & 41.38 & \\
\hline & & $3 \mathrm{Zn}$ & 34.88 & \\
\hline \multirow{3}{*}[\mathrm{ZnBr}_{2}\mathrm{L}]{$3 \mathrm{H}_{2} \mathrm{O}(\mathrm{C})$} & \multirow{3}{*}{946.26} & $1 \mathrm{Zn}$ & 32.19 & \multirow{3}{*}{695.4039} \\
\hline & & $2 \mathrm{Zn}$ & 39.25 & \\
\hline & & $3 Z n$ & 39.25 & \\
\hline$\left[\mathrm{ZnL}_{2}\left(\mathrm{OCH}_{2} \mathrm{CH}_{2} \mathrm{CH}_{2} \mathrm{CH}_{3}\right)_{2}\right](\mathrm{D})$ & 836.262 & $\mathrm{Zn}$ & 61.49 & 716.2531 \\
\hline$\left[\mathrm{Zn}\left(\mathrm{OClO}_{3}\right)_{2} \mathrm{~L}\right] \mathrm{HOCH}_{2} \mathrm{CH}_{2} \mathrm{CH}_{2} \mathrm{CH}_{3}(\mathrm{E})$ & 975.156 & $\mathrm{Zn}$ & 48.24 & 458.4137 \\
\hline
\end{tabular}

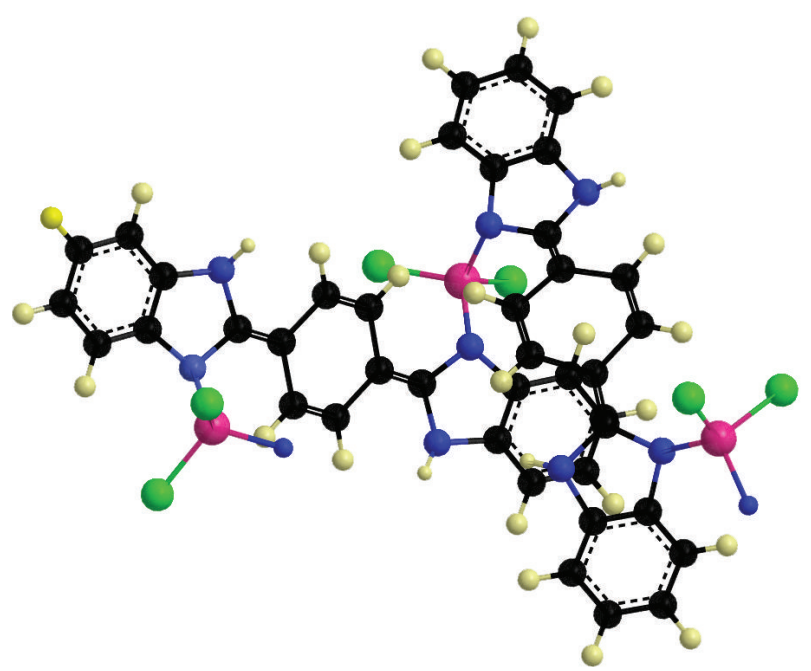

Figure 2: Molecular model: minimum energy configuration of $\left[\mathrm{ZnCl}_{2} \mathrm{~L}\right] \mathrm{H}_{2} \mathrm{O}$.

of n-butanol in DMSO- $\mathrm{d}_{6}$. The coordination-induced shifts for various protons of the coordinated ligands are in the range 0.01-0.46 ppm.

The ${ }^{13} \mathrm{C}$ NMR spectra of the ligand complex, $\left[\mathrm{Zn}\left(\mathrm{OClO}_{3}\right)_{2} \mathrm{~L}\right] \mathrm{HOCH}_{2} \mathrm{CH}_{2} \mathrm{CH}_{2} \mathrm{CH}_{3}$ complex, and $\left[\mathrm{ZnL}_{2}\left(\mathrm{OCH}_{2} \mathrm{CH}_{2} \mathrm{CH}_{2} \mathrm{CH}_{3}\right)_{2}\right]$ complex recorded in DMSO$\mathrm{d}_{6}$ reveal distinct resonances that are in agreement with the expected carbon environments and the data are collected in Table 3. The assignments of the signals are compared with the reported values for benzimidazole and substituted benzimidazoles $[24,25]$. The ${ }^{13} \mathrm{C}$ spectra for the chloro and bromo complexes could not be recorded due to their poor solubility in DMSO- $\mathrm{d}_{6}$. The resonance signal due to C-1' carbon is observed around $135.0 \mathrm{ppm}$. The resonance signal at $126.0 \mathrm{ppm}$ is assigned to $\mathrm{C}-2^{\prime}$ and $\mathrm{C}-6^{\prime}$ carbons. The resonances due to aromatic carbons of benzimidazole ring are found in the range 119.0 to $150.6 \mathrm{ppm}$. The resonance due to C-8 is observed around $150.0 \mathrm{ppm}$ and has shown positive coordination induced shift of $6.0 \mathrm{ppm}$. The C-9 carbon resonance signal is observed around $130.0 \mathrm{ppm}$.
In addition to the ligand resonance signals, the peaks of n-butanol are also observed. The resonance signal found at $13.8 \mathrm{ppm}$ indicates the presence of $-\mathrm{CH}_{3}$ group. The carbon atoms of the two $-\mathrm{CH}_{2}$ groups of $\mathrm{n}$-butanol resonate at 18.6 and $34.6 \mathrm{ppm}$. The carbon of $-\mathrm{CH}_{2}-\mathrm{O}-$ is observed at $60.3 \mathrm{ppm}$. Both positive and negative coordination-induced shifts are observed in the spectra of the complexes due to the ligand to metal $\sigma$-donation and metal-to-ligand $\pi$-donation, respectively [26].

Thermogravimetric analysis data of complex $\left[\mathrm{ZnL}_{2}\left(\mathrm{OCH}_{2} \mathrm{CH}_{2} \mathrm{CH}_{2} \mathrm{CH}_{3}\right)_{2}\right]$ has shown that there is a loss of a part of the solvent molecule $\left(\mathrm{CH}_{3} \mathrm{CH}_{2} \mathrm{CH}_{2}-\right)$ $(0.58 \%$, theoretical value $4.4 \%$ and found $5.1 \%)$ around $419^{\circ} \mathrm{C}$. The weight loss due to $1.42 \%$ solvent molecule $\left(\mathrm{OCH}_{2}-\right.$ and $\left.\mathrm{OCH}_{2} \mathrm{CH}_{2} \mathrm{CH}_{2} \mathrm{CH}_{3}\right)$ and two molecules of $\mathrm{N}$-heterocycle takes place in the temperature around $600^{\circ} \mathrm{C}$, which corresponds to a theoretical loss of $92.1 \%$ (found $93.4 \%)$. The final step of the decomposition corresponds to the formation of $\mathrm{ZnO}[27,28]$ :

$$
\begin{aligned}
{\left[\mathrm{ZnL}_{2}\left(\mathrm{OCH}_{2} \mathrm{CH}_{2} \mathrm{CH}_{2} \mathrm{CH}_{3}\right)_{2}\right] } & \\
& \stackrel{-\left(\mathrm{CH}_{2} \mathrm{CH}_{2} \mathrm{CH}_{3}\right)}{\stackrel{419^{\circ} \mathrm{C}}{\longrightarrow}}\left[\mathrm{ZnL}_{2}\left(\mathrm{OCH}_{2} \mathrm{CH}_{2} \mathrm{CH}_{2} \mathrm{CH}_{3}\right)\right]+\mathrm{OCH}_{3} \\
& \stackrel{598^{\circ} \mathrm{C}}{\longrightarrow} \mathrm{ZnO},-\left(\mathrm{OCH}_{2} \mathrm{CH}_{2} \mathrm{CH}_{2} \mathrm{CH}_{3}\right),-\mathrm{OCH}_{3},-2 \mathrm{~L}
\end{aligned}
$$

Molecular modeling studies were carried out with an interactive graphics molecular program [29]. Energy minimization was repeated several times to obtain the global minimum. The Leonnard-Jones equation was applied on $\mathrm{M}-\mathrm{N}$ bond to obtain a configuration with minimum repulsion and hence minimum steric strain. A representative example of the structure of the complex $\left[\mathrm{ZnCl}_{2} \mathrm{~L}\right] \mathrm{H}_{2} \mathrm{O}$, with minimum energy configuration, is shown in molecular model I (Figure 2). After global minimum configuration is attained, the total energy of the molecule in $\mathrm{kJ} / \mathrm{mol}$, percentage strain on the metal atom, and selected bond lengths, bond angles have been computed. The lowest energy of the complex is indicative of more stability; the values are given in Tables 4 and 5 .

Based on the above discussion, the chloro-, bromo-, and perchlorate-complexes are proposed to possess tetrahedral 
TABLE 5: Molecular modeling data.

\begin{tabular}{|c|c|c|c|c|c|c|c|c|c|c|c|c|}
\hline \multirow{2}{*}{$\begin{array}{l}\text { Compound } \\
\text { A }\end{array}$} & \multicolumn{4}{|c|}{ Bond length $(\AA)$} & \multicolumn{8}{|c|}{ Bond angle (degrees) } \\
\hline & - & & - & & - & & - & & - & & - & \\
\hline \multirow{6}{*}{ B } & $1 \mathrm{Zn}-2 \mathrm{~N}$ & 1.76 & $2 \mathrm{Zn}-6 \mathrm{~N}$ & 1.79 & $2 \mathrm{~N}-1 \mathrm{Zn}-3 \mathrm{~N}$ & 109.30 & $2 \mathrm{~N}-1 \mathrm{Zn}-1 \mathrm{Cl}$ & 110.94 & $2 \mathrm{~N}-1 \mathrm{Zn}-2 \mathrm{Cl}$ & 109.30 & $3 \mathrm{~N}-1 \mathrm{Zn}-2 \mathrm{Cl}$ & 109.26 \\
\hline & $1 \mathrm{Zn}-1 \mathrm{Cl}$ & 2.10 & $2 \mathrm{Zn}-4 \mathrm{Cl}$ & 2.10 & $3 \mathrm{~N}-1 \mathrm{Zn}-1 \mathrm{Cl}$ & 108.96 & $1 \mathrm{Cl}-1 \mathrm{Zn}-2 \mathrm{Cl}$ & 109.07 & $4 \mathrm{~N}-2 \mathrm{Zn}-3 \mathrm{Cl}$ & 108.45 & $4 \mathrm{~N}-2 \mathrm{Zn}-4 \mathrm{Cl}$ & 110.62 \\
\hline & $1 Z n-3 N$ & 1.82 & $3 Z n-9 N$ & 1.76 & $4 N-2 Z n-6 N$ & 110.85 & $6 \mathrm{~N}-2 \mathrm{Zn}-3 \mathrm{Cl}$ & 110.64 & $6 \mathrm{~N}-2 \mathrm{Zn}-4 \mathrm{Cl}$ & 107.28 & $9 N-3 Z n-10 N$ & 109.90 \\
\hline & $1 \mathrm{Zn}-2 \mathrm{Cl}$ & 2.10 & $3 \mathrm{Zn}-5 \mathrm{Cl}$ & 2.10 & $9 \mathrm{~N}-3 \mathrm{Zn}-5 \mathrm{Cl}$ & 109.93 & $9 \mathrm{~N}-3 \mathrm{Zn}-6 \mathrm{Cl}$ & 110.07 & $10 N-3 Z n-9 N$ & 109.90 & $10 N-3 Z n-5 C l$ & 109.92 \\
\hline & $2 \mathrm{Zn}-4 \mathrm{~N}$ & 1.77 & $3 \mathrm{Zn}-1 \mathrm{O}$ & 1.82 & $5 \mathrm{Cl}-3 \mathrm{Zn}-6 \mathrm{Cl}$ & 109.41 & & & & & & \\
\hline & $2 \mathrm{Zn}-3 \mathrm{Cl}$ & 2.10 & $3 \mathrm{Zn}-6 \mathrm{Cl}$ & 2.10 & & & & & & & & \\
\hline \multirow{5}{*}{$\mathrm{C}$} & $1 \mathrm{Zn}-2 \mathrm{~N}$ & 1.76 & $2 \mathrm{Zn}-4 \mathrm{~N}$ & 1.78 & $2 \mathrm{~N}-1 \mathrm{Zn}-1 \mathrm{Br}$ & 110.94 & $3 \mathrm{~N}-1 \mathrm{Zn}-2 \mathrm{Br}$ & 109.30 & $3 \mathrm{Br}-2 \mathrm{Zn}-7 \mathrm{~N}$ & 111.25 & $9 N-3 Z n-10 N$ & 110.07 \\
\hline & $1 \mathrm{Zn}-1 \mathrm{Br}$ & 2.28 & $2 \mathrm{Zn}-3 \mathrm{Br}$ & 2.28 & $2 \mathrm{~N}-1 \mathrm{Zn}-2 \mathrm{Br}$ & 109.30 & $3 \mathrm{~N}-1 \mathrm{Zn}-2 \mathrm{Br}$ & 109.24 & $4 \mathrm{Br}-2 \mathrm{Zn}-7 \mathrm{~N}$ & 105.26 & $10 N-3 Z n-5 B r$ & 110.06 \\
\hline & $1 \mathrm{Zn}-3 \mathrm{~N}$ & 1.82 & $2 \mathrm{Zn}-7 \mathrm{~N}$ & 1.79 & $2 \mathrm{~N}-1 \mathrm{Zn}-3 \mathrm{~N}$ & 109.31 & $4 \mathrm{~N}-2 \mathrm{Zn}-3 \mathrm{Br}$ & 107.01 & $9 N-3 Z n-5 B r$ & 110.04 & $10 N-3 Z n-6 B r$ & 109.87 \\
\hline & $1 \mathrm{Zn}-2 \mathrm{Br}$ & 2.27 & $2 \mathrm{Zn}-4 \mathrm{Br}$ & 2.28 & $3 \mathrm{~N}-1 \mathrm{Zn}-1 \mathrm{Br}$ & 108.74 & $4 \mathrm{~N}-2 \mathrm{Zn}-4 \mathrm{Br}$ & 111.23 & $9 N-3 Z n-6 B r$ & 110.08 & $5 \mathrm{Br}-3 \mathrm{Zn}-6 \mathrm{Br}$ & 106.67 \\
\hline & & & & & $4 N-2 Z n-7 N$ & 111.23 & & & & & & \\
\hline \multirow{2}{*}{$\mathrm{D}$} & $\mathrm{Zn}-1 \mathrm{~N}$ & 1.75 & $\mathrm{Zn}-2 \mathrm{O}$ & 1.78 & $1 \mathrm{~N}-\mathrm{Zn}-2 \mathrm{~N}$ & 109.45 & $1 \mathrm{~N}-\mathrm{Zn}-1 \mathrm{O}$ & 72.53 & 1O-An-2O & 110.83 & $1 \mathrm{O}-\mathrm{Zn}-2 \mathrm{~N}$ & 110.80 \\
\hline & $\mathrm{Zn}-1 \mathrm{O}$ & 1.77 & $\mathrm{Zn}-2 \mathrm{~N}$ & 1.78 & $1 \mathrm{~N}-\mathrm{Zn}-2 \mathrm{O}$ & 108.16 & & & & & & \\
\hline \multirow{2}{*}{$\mathrm{E}$} & $\mathrm{Zn}-\mathrm{N}$ & 1.79 & $\mathrm{Zn}-2 \mathrm{O}$ & 1.75 & $\mathrm{~N}-\mathrm{Zn}-1 \mathrm{O}$ & 98.379 & $\mathrm{~N}-\mathrm{Zn}-3 \mathrm{O}$ & 141.88 & $1 \mathrm{O}-\mathrm{Zn}-3 \mathrm{O}$ & 94.25 & $1 \mathrm{O}-\mathrm{Zn}-2 \mathrm{O}$ & 138.06 \\
\hline & $\mathrm{Zn}-1 \mathrm{O}$ & 1.76 & $\mathrm{Zn}-3 \mathrm{O}$ & 1.78 & $\mathrm{~N}-\mathrm{Zn}-2 \mathrm{O}$ & 95.25 & & & & & & \\
\hline
\end{tabular}

TABLE 6: Showing anthelmintic activity of synthesized complex compounds with standard.

\begin{tabular}{lcrc}
\hline Sl. no. & Group & Paralysis (in min) & Death (in min) \\
\hline 1 & Control (Tween80) & $221.17 \pm 0.48$ & $283.67 \pm 1.05$ \\
2 & Albendazole & $74.83 \pm 0.60$ & $105.67 \pm 0.67$ \\
3 & Piperazine citrate & $72.83 \pm 0.87$ & $108.83 \pm 0.60$ \\
4 & Ligand (L) & $78.36 \pm 0.15$ & $113.12 \pm 0.45$ \\
5 & {$\left[\mathrm{ZnCl}_{2} \mathrm{~L}\right] \mathrm{H}_{2} \mathrm{O}$} & $51.00 \pm 1.18$ & $96.83 \pm 0.48$ \\
6 & {$\left[\mathrm{ZnBr}_{2} \mathrm{~L}\right] 3 \mathrm{H}_{2} \mathrm{O}$} & $73.67 \pm 1.02$ & $89.00 \pm 0.58$ \\
7 & {$\left[\mathrm{ZnL}_{2}\left(\mathrm{OCH}_{2} \mathrm{CH}_{2} \mathrm{CH}_{2} \mathrm{CH}_{3}\right)_{2}\right]$} & $46.00 \pm 0.86$ & $66.50 \pm 0.62$ \\
8 & {$\left[\mathrm{Zn}\left(\mathrm{OClO}_{3}\right)_{2} \mathrm{~L}\right] \mathrm{HOCH}_{2} \mathrm{CH}_{2} \mathrm{CH}_{2} \mathrm{CH}_{3}$} & $91.00 \pm 0.97$ & $136.50 \pm 0.76$ \\
\hline
\end{tabular}

geometry. In the case of the perchlorate complex, at least one perchlorate monodentately coordinated to the metal ion as supported by IR spectrum. The molecular modeling suggests that the $\mathrm{N}$-heterocycles act as bridging ligand and, therefore, have a polymeric structure. In the case of $\left[\mathrm{ZnL}_{2}\left(\mathrm{OCH}_{2} \mathrm{CH}_{2} \mathrm{CH}_{2} \mathrm{CH}_{3}\right)_{2}\right]$ complex, ${ }^{1} \mathrm{H}$ and ${ }^{13} \mathrm{C} \mathrm{NMR}$ spectral studies and the thermogravimetric data show the presence of two solvent molecules, that is, n-butanol, which are coordinated to the metal ion through oxygen atom, and the complex is also proposed to have tetrahedral geometry around the metal ion.

\section{Anthelmintic Activities of Synthesized Complex}

The results revealed that synthesized complexes have significant anthelmintic activity at $5 \mathrm{mg} / \mathrm{mL}$ concentrations. The results are comparable with standard drugs albendazole and piperazine citrate at the same concentration. Table 6 reveals that almost all complexes showed a significant

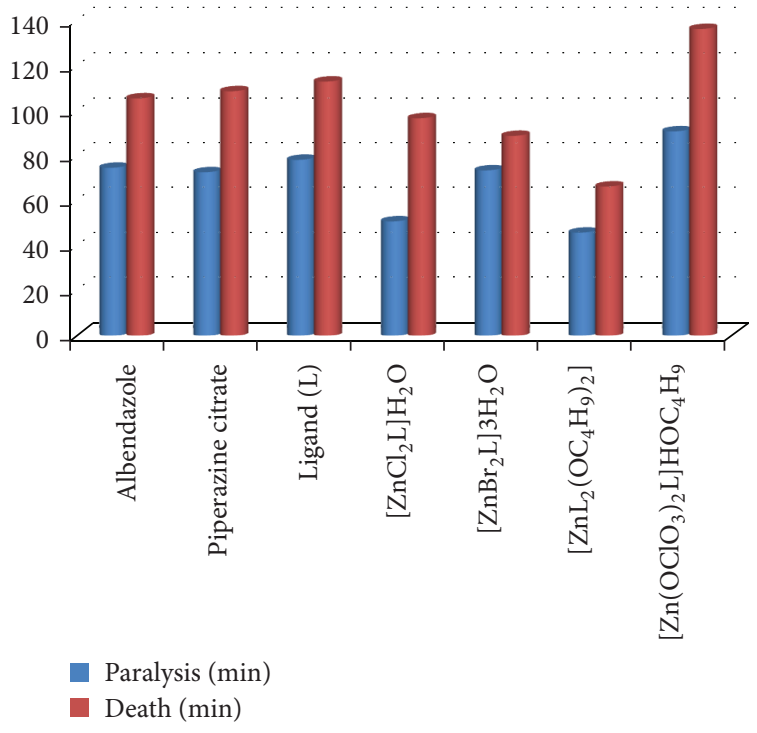

FIGURE 3: Anthelmintic activity. 
activity compared to the standard drug, as well as the ligand; and out of four synthesized complexes, $\left[\mathrm{Zn}\left(\mathrm{OClO}_{3}\right)_{2}\right.$ L] $\mathrm{HOCH}_{2} \mathrm{CH}_{2} \mathrm{CH}_{2} \mathrm{CH}_{3}$ complex showed less anthelmintic activity (Figure 3 ).

\section{Acknowledgments}

The author would like to thank Shashikala Narashimaiah Department of Studies in Chemistry, Bangalore University, Central College Campus, Bangalore-560 001, India. The author is also thankful to Professor D. N. Sathyanarayana, Indian Institute of Science, Bangalore, India, Professor B. K. Sadashiva, Raman Research Institute, Bangalore, India, and the authority of the Sophisticated Instruments Facility, Indian Institute of Science, Bangalore, India for recording NMR spectra. The author is also thankful to UGC-DRS Programme for the financial assistance to the department.

\section{References}

[1] N. Shashikala, V. Gayathri, N. M. Nanjegowda, and G. K. N. Reddy, "Reactions of 2,6-bis(2-benzimidazyl)pyridine with some acids and cobalt(II) and nickel(II) salts," Journal of Indian Chemical Society, vol. 66, pp. 537-540, 1989.

[2] V. Gayathri, N. Shashikala, N. M. Nanjegowda, and G. K. N. Reddy, "Synthesis and spectral properties of 1,3bis(2-benzimidazyl)benzene and its N-methylated derivativereactions with some acids and cobalt(II) salts," Indian Journal of Chemistry A, vol. 32, pp. 33-38, 1993.

[3] S. Satyanarayana and K. R. Nagasundara, "Synthesis and spectral properties of the complexes of cobalt(II), nickel(II), copper(II), zinc(II), and cadmium(II) with 2-(thiomethyl-2' benzimidazolyl)-benzimidazole," Synthesis and Reactivity in Inorganic and Metal-Organic Chemistry, vol. 34, no. 5, pp. 883-895, 2004.

[4] N. Shivakumaraiah and N. M. Nanjegowda, "Reactions of zinc salts with bis(benzimidazolyl) derivatives," Synthesis and Reactivity in Inorganic and Metal-Organic Chemistry, vol. 33, no. 7, pp. 1207-1220, 2003.

[5] S. Ruttimann, G. Bernardinelli, and A. F. Williams, "Synthesis and structure of a trimeric cyclometalated coordination compound with a hydrophobic cavity," Angewandte Chemie, vol. 32, no. 3, pp. 392-394, 1993.

[6] A. W. Addsion, T. Nageswara Rao, J. Reedijk, J. C. Rijn, and G. C. Verschoor, "Synthesis, structure, and spectroscopic properties of copper(II) compounds containing nitrogen-sulphur donor ligands; the crystal and molecular structure of aqua[1,7-bis(N-methylbenzimidazol-2' $-\mathrm{yl})-2,6-$ dithiaheptane]copper(II) perchlorate," Journal of the Chemical Society, Dalton Transactions, no. 7, pp. 1349-1356, 1984.

[7] A. E. Martel, Metal Ions in Biological Systems, vol. 2, Marcel Dekker, New York, NY, USA, 1973.

[8] K. D. Karlin and J. Zubieta, Biological and Inorganic Copper Chemistry, Adenine Press, New York, NY, USA, 1986.

[9] R. H. Prince, "Some aspects of the bioinorganicchemistry of zinc," Advances in Inorganic Chemistry and Radiochemistry, vol. 22, pp. 349-440, 1979.

[10] S. Chandra, S. Parmar, and Y. Kumar, "Synthesis, spectroscopic, and antimicrobial studies on bivalent zinc and mercury complexes of 2-formylpyridine thiosemicarbazone," Bioinorganic
Chemistry and Applications, vol. 2009, Article ID 851316, 6 pages, 2009.

[11] M. I. Zaidi, F. H. Wattoo, M. H. S. Wattoo, S. A. Tirmizi, and S. Salman, "Antibacterial activities of nicotine and its zinc complex," African Journal of Microbiology Research, vol. 6, no. 24, pp. 5134-5137, 2012.

[12] S. S. Kukalenko, B. A. Bovykin, S. I. Shestakova, and A. M. Ometchenko, "Metal-containing complexes of lactams, imidazoles, andbenzimidazoles and their biological activity," Russian Chemical Reviews, vol. 54, no. 7, article 676, 1985.

[13] I. Tamm, R. Bablanian, M. M. Nemes, C. H. Shunk, F. M. Robinson, and K. Folkers, "Relationship between structure of benzimidazole derivatives and selective virus inhibitory activity. Inhibition of poliovirus multiplication and cytopathic effects by 2-(alpha-hydroxybenzyl)-benzimidazole, and its 5chloroderivative," Journal of Experimental Medicine, vol. 113, pp. 625-656, 1961.

[14] D. D. Perrin, W. L. F. Armarego, and D. R. Perrin, Purification of Laboratory Chemicals, Pergaman Press, Oxford, UK, 1966.

[15] F. Bei, F. F. Jian, X. Yang et al., "1,4-bis(2-benzimidazolyl)benzene," Acta Crystallographica C, vol. 56, pp. 718-719, 2000.

[16] E. O. Ajaiyeoba, P. A. Onocha, and O. T. Olarenwaju, "In vitro anthelmintic properties of Buchholzia coriaceae and Gynandropsis gynandra extracts," Pharmaceutical Biology, vol. 39, no. 3, pp. 217-220, 2001.

[17] W. J. Geary, "The use of conductivity measurements in organic solvents for the characterisation of coordination compounds," Coordination Chemistry Reviews, vol. 7, no. 1, pp. 81-122, 1971.

[18] T. J. Lane, I. Nakagawa, J. L. Walter, and A. J. Kandathil, "Infrared investigation of certain imidazole derivatives and their metal chelates," Inorganic Chemistry, vol. 1, no. 2, pp. 267-276, 1962.

[19] E. W. Ainscough, A. M. Brodie, and N. G. Larsen, "Sulphur ligand metal complexes. Part 15. [1].Sulphurnitrogen donor ligand complexes of copper," Inorganica Chimica Acta, vol. 60, pp. 25-34, 1982.

[20] K. Nakamoto, Infrared Spectra of Inorganic and Coordination Compounds, Wiley Interscience, John Wiley \& Sons, NewYork, NY, USA, 2nd edition, 1970.

[21] N. M. N. Gowda, S. B. Naikar, and G. K. N. Reddy, "Perchlorate Ion complexes," Advances in Inorganic Chemistry, vol. 28, pp. 255-299, 1984.

[22] L. J. Bellamy, The Infrared Spectra of Complex Molecules, Chapman and Hall, London, UK, 1975.

[23] K. Nakanishi and P. H. Soloman, Infrared AbsorptionSpectroscopy, Holden-Day, Sydney, Australia, 1977.

[24] R. J. Pugmire and D. M. Grant, "Carbon-13 magnetic resonance. XIX. Benzimidazole, purine, and their anionic and cationic species," Journal of the American Chemical Society, vol. 93, no. 8, pp. 1880-1887, 1971.

[25] L. J. Mathias and C. G. Overberger, "Carbon-13 nuclear magnetic resonance chemical shifts of substituted benzimidazoles and 1,3-diazaazulene," Journal of Organic Chemistry, vol. 43, no. 18, pp. 3526-3530, 1978.

[26] X. Xiamong, M. Haga, T. Matsumura-Inoue, Y. Ru, A. W. Addison, and K. Kano, "Synthesis and proton transfer-linked redox tuning of ruthenium(II) complexes with tridentate 2,6bis(benzimidazol-2-yl)pyridine ligands," Journal of the Chemical Society, Dalton Transactions, no. 16, pp. 2477-2484, 1993. 
[27] S. Wang, Q. Luo, X. Zhou, and Z. Zeng, "Synthesis, characterization and luminescence properties of lanthanide(III) complexes with 2,6-bis(benzimidazol-2' -yl)pyridine," Polyhedron, vol. 12, no. 15, pp. 1939-1945, 1993.

[28] J. R. Allan, J. G. Bonner, D. L. Gerrard, and Mirmied, "Structural characterisation and thermal analysisstudies of the compounds of manganese(II), cobalt(II), nickel(II), copper(II) and zinc(II) with poly(crylic acid)," Thermochimica Acta, vol. 185, no. 2, pp. 295-302, 1991.

[29] Full working trial version, Molecular Modeling Pro plus published by ChemSW(R). 

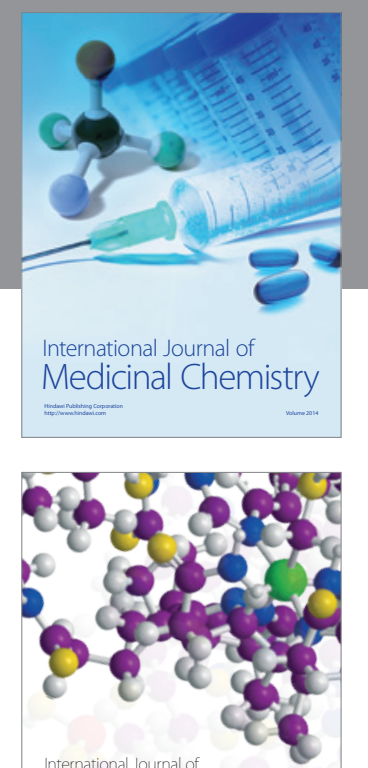

\section{Carbohydrate} Chemistry

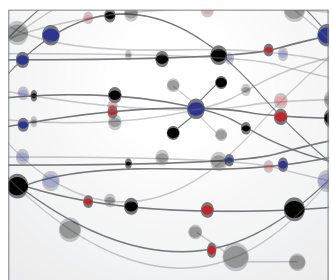

The Scientific World Journal
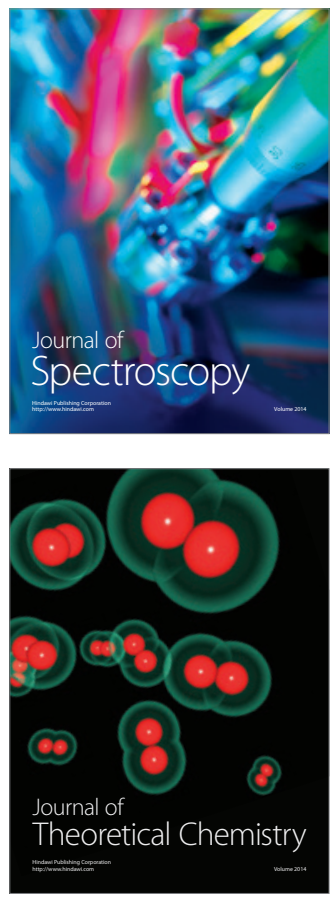
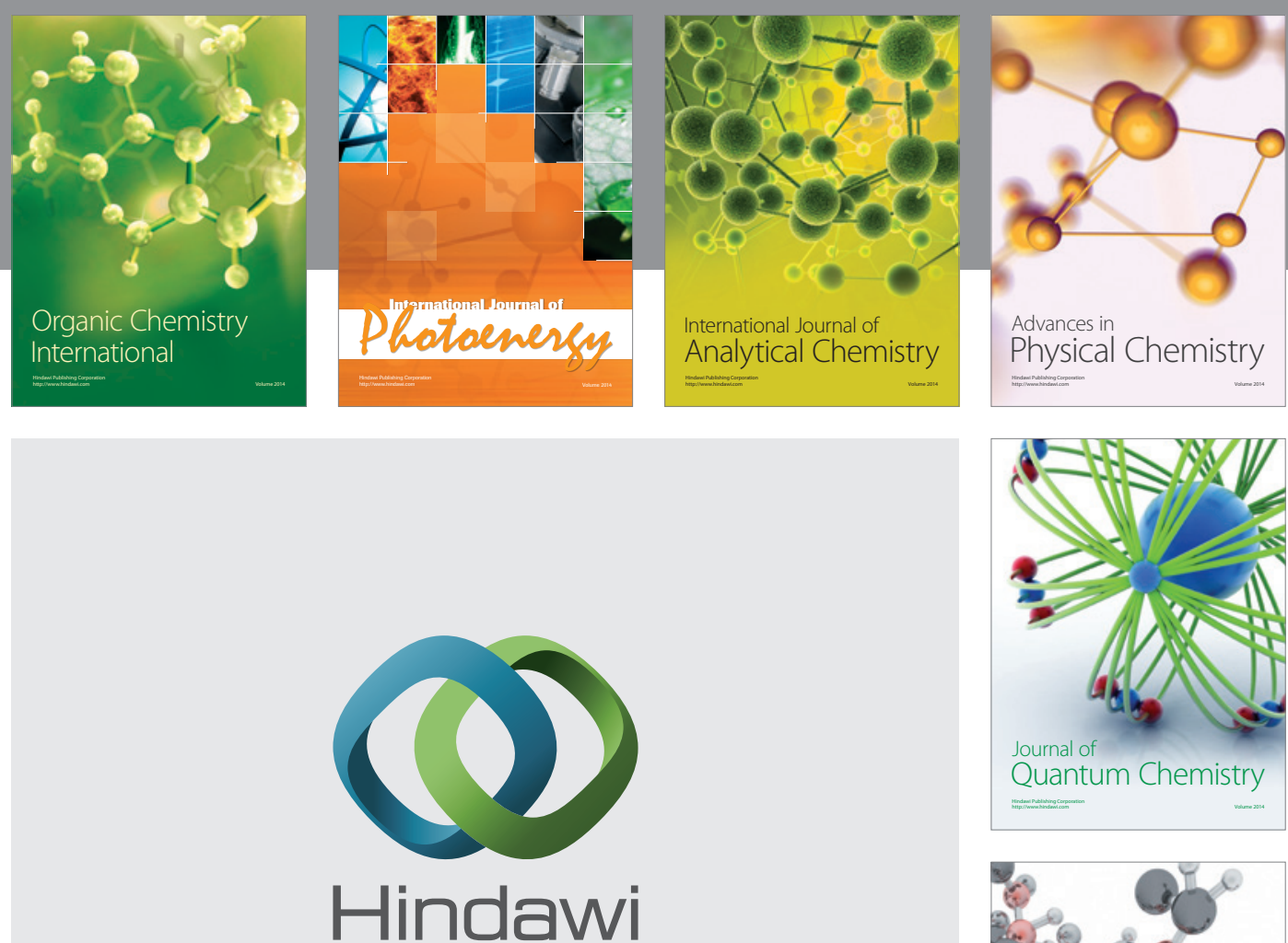

Submit your manuscripts at

http://www.hindawi.com

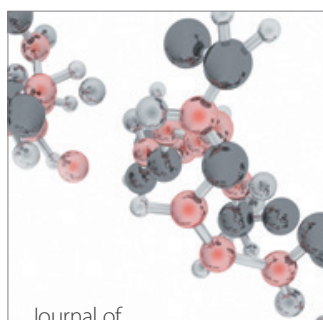

Analytical Methods

in Chemistry

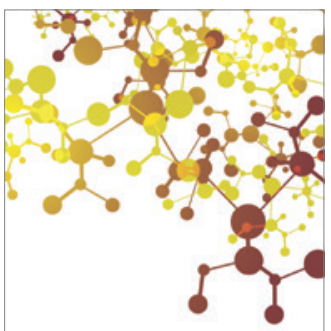

Journal of

Applied Chemistry

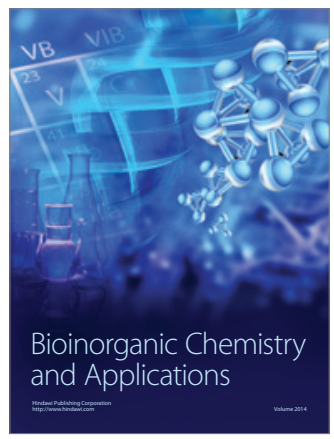

Inorganic Chemistry
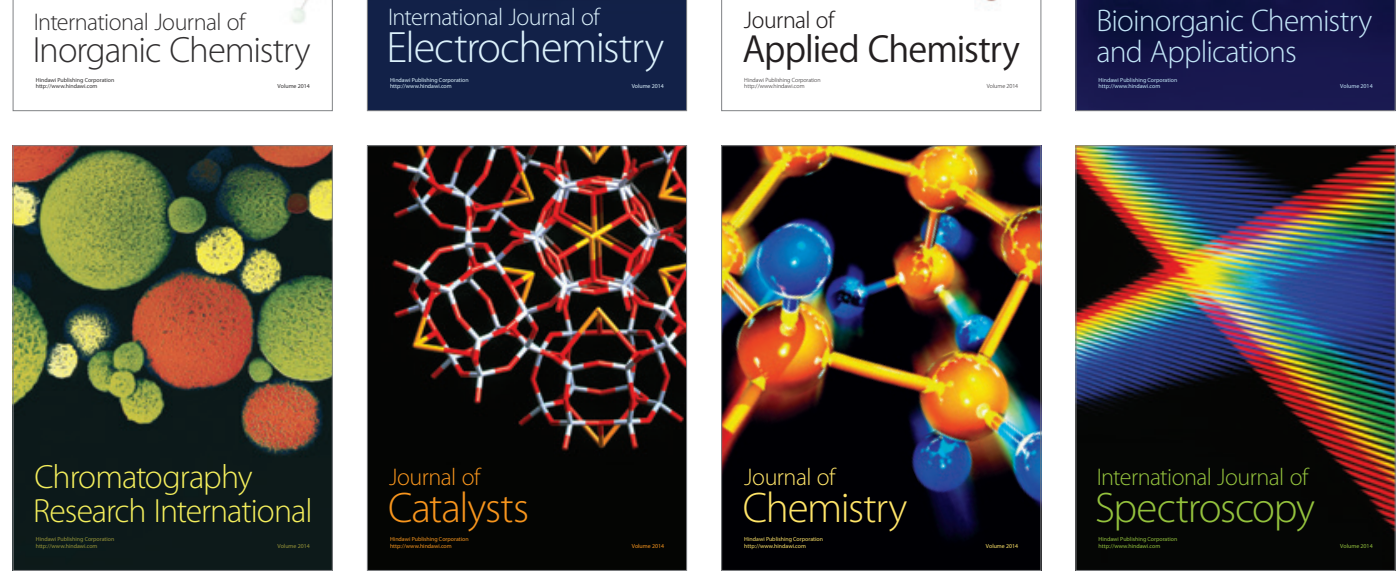